\title{
Morphological and biochemical parameters of cow blood when using chitosan preparations
}

\author{
V.S. Gorelik ${ }^{1}$, M.B. Rebezov ${ }^{1,2,3,}{ }^{*}$, N.L. Lopaeva ${ }^{1}$, E.S. Smirnova ${ }^{1}$, and S.K. Sultanova ${ }^{3}$ \\ ${ }^{1}$ Ural State Agricultural University, Karl Liebknecht str., 42, 620075 Yekaterinburg, Russian \\ Federation \\ ${ }^{2}$ V.M. Gorbatov Federal Research Center for Food Systems of Russian Academy of Sciences, \\ Talalikhina St., 26, 109316 Moscow, Russian Federation \\ ${ }^{3}$ K.G. Razumovsky Moscow State University of technologies and management (The First Cossack \\ University), Zemlyanoy Val, 73, 109004 Moscow, Russian Federation
}

\begin{abstract}
The study of the effect of chitosan succinate use on the hematological indicators of dairy cows is relevant. It has been established that there was a clear tendency to increase in the number of white blood cells by $10.12 \%$ in animals of group $3(\mathrm{P}<0.1)$ on the 10 th day of the experiment in cows receiving low-molecular-weight chitosan succinate, in the second group the increase in this indicator by $2.94 \%$ was unreliable. On the 20th day of the experiment, an intensive increase in the number of white blood cells was observed in animals of both experimental groups by $14.63-17.38 \%(\mathrm{P} \leq 0.01)$, respectively, for the experimental groups of cows. On the 10th day on the background of the use of low-molecular-weight chitosan (group 3), a significant decrease in the number of red blood cells was found, compared with the background, by $8.34 \%(\mathrm{P} \leq 0.05)$. On the 20 th day, the decrease in the number of red blood cells was already significant in both experimental groups, and their level was $6.09 \pm 0.33 \ldots 6.38 \pm 0.20 \cdot 109 / 1(\mathrm{P} \leq 0.05)$, respectively. On the 60th day of the study, this trend was maintained only in group 3, and the concentration of red blood cells was lower by $12.64(\mathrm{P}<0.05)$ compared to the initial values. By the 60th day, there was an increase in the level of hemoglobin index up to $126.12 \pm 9.10 \mathrm{~g} / 1$.
\end{abstract}

\section{Introduction}

Continuous and sustainable provision of high-quality food products, including milk, is the main necessity in ensuring the health of the nation and food security of any country [17]. At the same time, special attention is paid to the development of dairy cattle breeding, since the main amount, more than $97 \%$ of the total production, is obtained from cattle, a valuable food product and raw material for the dairy industry - milk. Milk provides a person with full-fledged essential nutrients and is well absorbed by the body. The increase in cow productivity should be inseparably linked with milk quality improvement, which has a significant impact on the quality of finished dairy products [8-18]. Obtaining it in the

\footnotetext{
*Corresponding author: rebezov@yandex.ru
} 
conditions of the zone of man-made pollution impact imposes special requirements on manufacturers to ensure the safety of the product. The use of natural feed additives with ion-exchange and adsorbing properties makes it possible to obtain a safe product [19-27]. The study of such feed additives effect on the hematological and biochemical blood parameters of cows is relevant and has practical significance.

The purpose of the work is to study the effect of chitosan succinate in cow feeding on their hematological parameters.

\section{Materials and method}

The studies were carried out on cows of the black-and-white breed for the III lactation in the Agricultural Production Co-operative Collective Farm "Rassvet". 3 groups of animals were selected by balanced group method, taking into account age, productivity for the previous lactation, breed characteristics, live weight, etc., 15 heads each. During the study period, the animals were kept in the same feeding and maintenance conditions in accordance with zoohygienic requirements. The first group of cows served as a control one. The animals of the second group were treated with high-molecular-weight chitosan succinate with a molecular weight of $487.0 \mathrm{kDa}$ and a deacetylation degree of $75.3 \%$. Cows of the third group received low-molecular-weight chitosan succinate with a molecular weight of $38 \mathrm{kDa}$ and a degree of substitution of $85 \%$. The drugs were administered orally in the form of a $2 \%$ solution of $2.0 \mathrm{ml}$ per $1 \mathrm{~kg}$ of live weight 2 times a day for seven days. After 5 days, the administration was repeated.

\section{Results}

The main parameter of red blood is red blood cells, which are directly involved in the transport of oxygen and carbon dioxide, as well as nutrient and biologically active compounds [19]. The obtained results of the studies revealed a positive effect of chitosan preparations on the morphological parameters of the blood (fig. 1.)

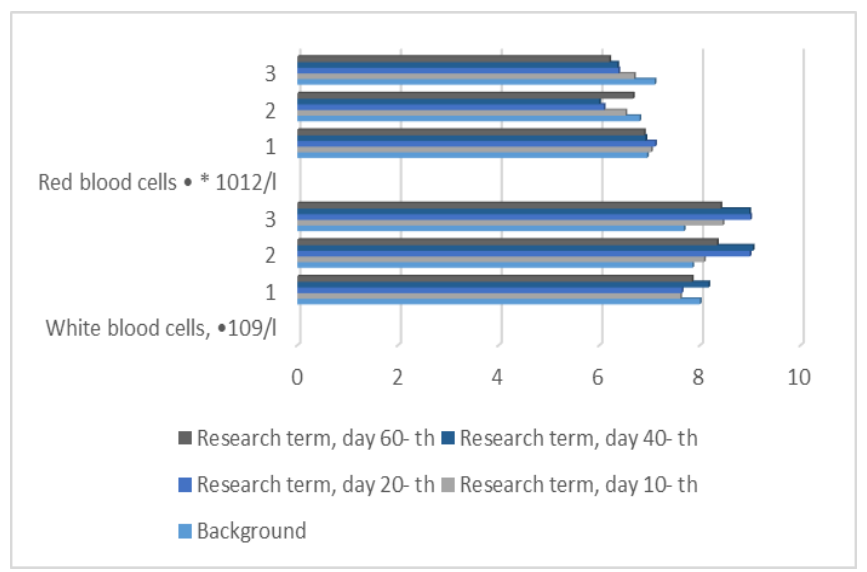

Fig. 1. The content of white blood cells and red blood cells in cows according to the study periods.

The study of white blood cells and red blood cells content in the blood of cows shows that the use of low-molecular-weight chitosan (group 3) had a greater effect. On the 10th day of the experiment there was a clear tendency to increase in the number of white blood cells by $10.12 \%$ in animals of group $3(\mathrm{P}<0.1)$, in the second group the increase in this 
indicator by $2.94 \%$ was unreliable. On the 20th day of the experiment, an intensive increase in the number of white blood cells was observed in animals of both experimental groups by $14.63-17.38 \%(\mathrm{P} \leq 0.01)$, respectively, for the experimental groups of cows. On the 40th day of observation, the level of white blood cells basically did not change, and on the 60th day, there was a significant decrease in this indicator in the blood of cows of the second group by $9.21 \%$ and the third by $7.43 \%(\mathrm{P} \leq 0.05$, in both groups $)$, compared to the previous period.

Significant changes were also noted in the dynamics of red blood cells level in the blood of cows. On the 10th day on the background of the use of low-molecular-weight chitosan (group 3), a significant decrease in the number of red blood cells was found, compared with the background, by $8.34 \%(\mathrm{P} \leq 0.05)$. On the 20th day, the decrease in the number of red blood cells was already significant in both experimental groups, and their level was $6.09 \pm 0.33 \ldots 6.38 \pm 0.20 \cdot 10^{9} / 1(\mathrm{P} \leq 0.05)$, respectively. On the 60 th day of the study, this trend was maintained only in group 3, and the concentration of red blood cells was lower by $12.64(\mathrm{P}<0.05)$ compared to the initial values.

The use of chitosan preparations contributed to the normalization of the hemoglobin level, the concentration of which in the period from the 20th to the 40th day of the experiment corresponded to the reference values. By the 60th day, there was an increase in the level of this indicator up to $126.12 \pm 9.10 \mathrm{~g} / \mathrm{l}$ (fig. 2.).

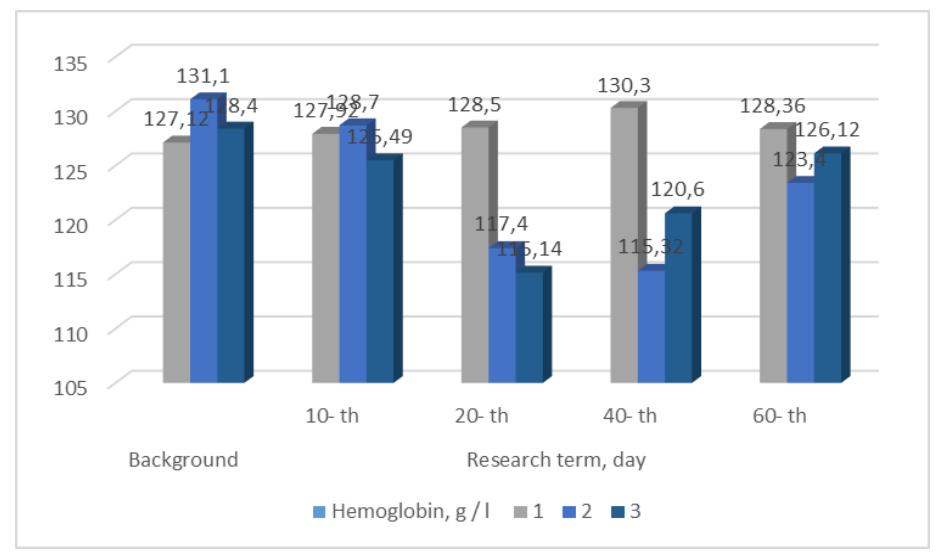

Fig. 2. The content of hemoglobin by study period.

Analysis of the dynamics of protein metabolism indicators against the background of chitosan preparations shows that the total protein content of cow blood serum by the 20th day of the experiment increased by $13.00 \ldots 14.59 \%$ and this trend continued in the subsequent periods (fig. 3.). 


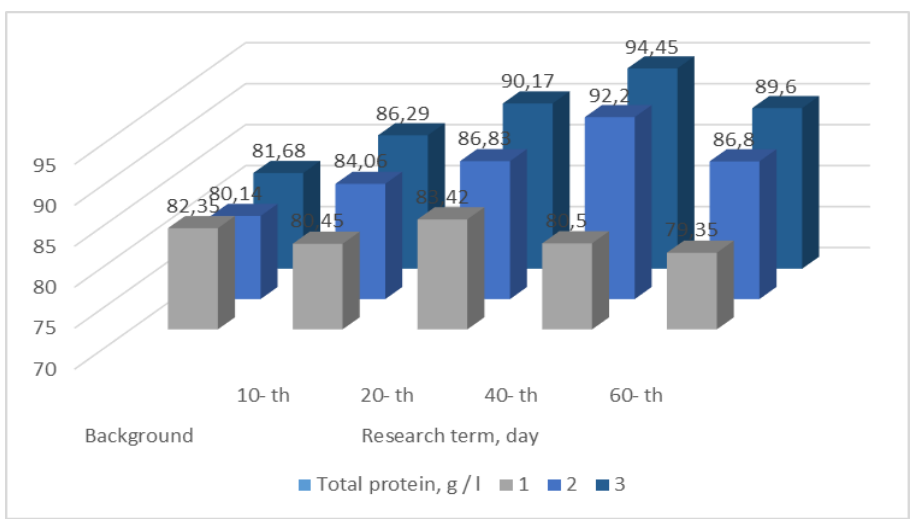

Fig. 3. Total protein content in the blood of cows according to the study periods.

Thus, its significant increase on the 40th day of the experiment was noted in animals of the group 2 up to $92.20 \pm 0.45 \mathrm{~g} / 1$ and up to $94.45 \pm 0.19 \mathrm{~g} / 1$ - in animals of the group 3 against $81.39 \pm 0.30 \mathrm{~g} / \mathrm{l}$ of the mean baseline $(\mathrm{P}<0.01)$. By the end of the experiment, there was a slight decrease in the total protein content in both the control and experimental groups; nevetheless, against the background of the use of chitosan, the decrease was insignificant, and the total protein level continued to remain higher than the background values in groups 2 and 3 by $8.31 \%$ and $9.69 \%$, respectively $(\mathrm{P}<0.05)$, while in the control group it became $3.65 \%$ lower than the initial indicator.

\section{Discussion}

Evaluation of the impact of feed additives use on the physiological state of cows, namely their hematological indicators are important for improving the productivity, quality indicators of milk and productive longevity of cows. Similar studies were conducted by V.S. Gorelik, A.R. Tairova [19], N.V. Bogolyubova, V.P. Korotky, A.S. Zenkin, V.A. Ryzhov, N.P. Buryakov [23,24], Gorelik O. V., Gafner V. D., Nesterenko A. A., Dolmatova I. A., Safronov S. L., Odah Gi Aksel [21], Mymrin V and Loretts O [22], O V Gorelik, O E Lihodeevskaya, N N Zezin, M Ya Sevostyanov and O I Leshonok [25-29].

\section{Conclusion}

Based on the above, it can be concluded that the use of chitosan succinate with different molecular weights in feeding of cows can improve their physiological state and metabolism in the body. The use of low-molecular-weight chitosan (group 3) had a greater effect on the morphological parameters of the blood of experimental animals.

\section{References}

1. O. Gorelik, M. Rebezov, A. Gorelik, S. Harlap, I. Dolmatova, T. Zaitseva, N. Maksimuk, N. Fedoseeva, N. Novikova, International Journal of Innovative Technology and Exploring Engineering, 8(7), 559 (2019)

2. O. Gorelik et al, International Journal of Pharmaceutical Research (2019)

3. O. Gorelik et al, Annual Research \& Review in Biology, 18(4) 1 (2017)

4. O. Gorelik et al, AIP Conference Proceedings, 2207, 020012 (2020) 
5. A. Belookov, O. Belookova, V. Zhuravel, S. Gritsenko, I. Bobyleva, E. Ermolova, S. Ermolov, Y. Matrosova, M. Rebezov, E. Ponomarev, International Journal of Engineering and Advanced Technology, 8(4), 1058 (2019)

6. F. Khaziakhmetov et al, Research Journal of Pharmaceutical, Biological and Chemical Sciences, 9(3), 866 (2018)

7. F. Khaziakhmetov, A. Khabirov, M. Rebezov, A. Basharov, I. Ziangulov, E. Okuskhanova, International Journal of Veterinary Science, 7(4), 178 (2018)

8. A. Gorelik et al, Advances in Agricultural and Biological Sciences, 2(1), 5 (2016)

9. O.V. Gorelik et al, Advances in Agricultural and Biological Sciences, 2(1), 27 (2016)

10. F. Smolnikova, Z. Moldabayeva, M. Klychkova, O. Gorelik, R. Khaybrakhmanov, I. Mironova, A. Kalimullin, G. Latypova, International Journal of Innovative Technology and Exploring Engineering, 8(7), 670 (2019)

11. N. Chernopolskaya, N. Gavrilova, M. Rebezov, S. Harlap, A. Nigmatyanov, G. Peshcherov, T. Bychkova, K. Vlasova, I. Karapetyan, International Journal of Pharmaceutical Research, 11(1), 545 (2019)

12. N. Chernopolskaya, N. Gavrilova, M. Rebezov, I. Dolmatova, T. Zaitseva, Y. Somova, M. Babaeva, E. Ponomarev, O. Voskanyan, International Journal of Engineering and Advanced Technology, 8(4), 40 (2019)

13. N. Gavrilova, N. Chernopolskaya, M. Rebezov, D. Moisejkina, I. Dolmatova, I. Mironova, G. Peshcherov, O. Gorelik, M. Derkho, International Journal of Recent Technology and Engineering, 8(2), 2718 (2019)

14. N. Gavrilova, N. Chernopolskaya, M. Rebezov, E. Shchetinina, I. Suyazova, S. Safronov, V. Ivanova, E. Sultanova, Journal of Critical Reviews, 7(4) 233 (2020)

15. M. Temerbayeva et al, Annual Research \& Review in Biology, 23(6), 1 (2018)

16. M. Temerbayeva et al, Research journal of pharmaceutical biological and chemical sciences, 9(1), 291 (2018)

17. A. Serikova, F. Smolnikova, M. Rebezov, E. Okuskhanova, M. Temerbayeva, O. Gorelik, S. Harlap, Sh. Baitukenova, S. Baitukenova, Y. Tumbasova, Research Journal of Pharmaceutical, Biological and Chemical Sciences, 9(4) 495 (2018)

18. F. Smolnikova, S. Toleubekova, M. Temerbayeva, E. Cherkasova, O.K. Gorelik, S. Harlap, M. Derkho, M. Rebezov, I. Penkova, Journal of Pharmaceutical, Biological and Chemical Sciences, 9(3) 1003 (2018)

19. V.S. Gorelik, A.R. Tairova, Proceedings of the Orenburg State Agrarian University, 6(44), 98 (2013)

20. N. Kuramshina, M. Rebezov, E. Kuramshin, L. Tretyak, G. Topuria, D. Kulikov, A. Evtushenko, S. Harlap, E. Okuskhanova, International Journal of Pharmaceutical Research, 11(1), 1301 (2019)

21. E. Skvortsov, O. Bykova, V. Mymrin, E. Skvortsova, O. Neverova, V. Nabokov, V. Kosilov, The Turkish Online Journal of Design Art and Communication, 8, 291 (2018)

22. O.V. Gorelik, V.D. Gafner, A.A. Nesterenko, I.A. Dolmatova, S.L. Safronov, Odah Gi Aksel, IOP Conf. Series: Earth and Environmental Science, 613 (2020)

23. V. Mymrin, O. Loretts, Proceedings of the International Scientific and Practical Conference (ISPC 2019) Advances in Intelligent Systems Research, 511 (2019)

24. S. Gridina, V. Gridin, O. Leshonok, Advances in Engineering Research, 253 (2018)

25. N. Bogolyubova, V. Korotky, A. Zenkin, V. Ryzhov, N. Buryakov, OnLine Journal of 
Biological Sciences, 17(2), 121 (2017)

26. N. Bogolyubova, V. Romanov, V. Korotky, V. Ryzhov, A. Zenkin, Asian Journal of Pharmaceutical and Clinical Research, 10(10), 117 (2017)

27. O.V. Gorelik et al, IOP Conf. Ser.: Earth Environ. Sci., 548, 082009 (2020)

28. O.V. Gorelik et al, IOP Conf. Ser.: Earth Environ. Sci. (2020)

29. O. Gorelik et al, AIP Conference Proceedings, 2207, 020012 (2020) 